\title{
Pengaruh Problem Based Learning Berbantuan Media Youtube Terhadap Kemampuan Literasi Numerasi Siswa
}

\author{
Dyah Ambarwati ${ }^{1}$, Meyta Dwi Kurniasih ${ }^{2}$ \\ 1,2 Prodi Pendidikan Matematika, Fakultas Keguruan dan Ilmu Pendidikan, Universitas Muhammadiyah Prof. Dr. Hamka, \\ Jl. Tanah Merdeka No. 20, Rambutan, Jakarta Timur, Indonesia \\ dyahambarwati62@gmail.com
}

\begin{abstract}
The low numeracy literacy ability of students is caused by the selection of inexact learning models and media. The research aimed to determine the effect of Problem Based Learning assisted with YouTube media on a student's numeracy literacy ability. The research method used is quantitative, the type is True Experiment. The design used is a posttest only control group design. The population of this study was all eight grade students of SMPN 62 Jakarta. The subject of this study consisted of 2 classes, class VIII- 4 as the experimental class and class VIII- 3 as the control class. The sampling technique used cluster random sampling where both classes were normally distributed and homogeneous. The instrument used is a test of numeracy literacy that has been tested for validity and reliability. The results of testing the t-test hypothesis obtained $t_{\text {count }}=3,339>t_{\text {table }}=1,994$ at a significant level of 0.05 , thus $H_{o}$ is rejected, so there is a significant difference between the experimental class and the control class. Then Effect Size of 0.710 was obtained with a medium category. So, Problem Based Learning assisted with YouTube media influences the numeracy literacy ability of class VIII students.
\end{abstract}

Keywords: Problem Based Learning, YouTube Media, Numeracy Literacy

\begin{abstract}
Abstrak
Rendahnya kemampuan literasi numerasi siswa disebabkan karena pemilihan model dan media pembelajaran yang kurang sesuai. Penelitian ini bertujuan untuk mengetahui pengaruh Problem Based Learning berbantu media YouTube terhadap kemampuan literasi numerasi siswa. Metode penelitian yang digunakan adalah kuantitatif, jenis True Eksperiment. Desain yang digunakan Posttest only control group design. Populasi penelitian ini adalah seluruh siswa kelas VIII SMPN 62 Jakarta. Sampel penelitian ini terdiri dari 2 kelas, yaitu kelas VIII-4 sebagai kelas eksperimen dan kelas VIII-3 sebagai kelas kontrol. Teknik pengambilan sampel menggunakan cluster random sampling dimana kedua kelas berdistribusi normal dan homogen. Adapun instrumen yang digunakan, yaitu tes kemampuan literasi numerasi yang telah di uji validitas dan reliabilitasnya. Hasil pengujian hipotesis uji- $t$ diperoleh $t_{\text {hitung }}=3,339>t_{\text {tabel }}=1,994$ pada taraf signifikan 0,05 dengan demikian $H_{o}$ ditolak, sehingga terdapat perbedaan yang signifikan antara kelas eksperimen dengan kelas kontrol. Kemudian diperoleh nilai Effect Size sebesar 0,710 dengan interpretasi kategori sedang. Maka, Problem Based Learning berbantuan media YouTube memberikan pengaruh terhadap kemampuan literasi numerasi siswa kelas VIII.
\end{abstract}

Kata kunci: Problem Based Learning, Media YouTube, Literasi Numerasi

Copyright (c) 2021 Dyah Ambarwati, Meyta Dwi Kurniasih

$\triangle$ Corresponding author: Dyah Ambarwati

Email Address: dyahambarwati62@gmail.com (Jl. Tanah Merdeka No. 20, Rambutan, Jakarta Timur, Indonesia)

Received 07 July 2021, Accepted 31 August 2021, Published 04 September 2021

\section{PENDAHULUAN}

Pada abad 21 ini Ilmu Pengetahuan dan Teknologi (IPTEK) berkembang dengan pesat, terutama dalam informasi dan komunikasi. Hal ini memberi dampak pada berbagai bidang kehidupan, salah satu yang berdampak sangat besar adalah bidang pendidikan. Pendidikan akan mengalami perkembangan mulai dari kurikulum, model, strategi, dan media pembelajaran. Dimana semakin berkembangnya zaman, akan ada sebuah pembaharuan teknologi yang bertujuan untuk mencapai pendidikan yang berkualitas. 
Tahun 2016 Kementerian Pendidikan dan Kebudayaan mengadakan berbagai kegiatan dalam mendorong literasi nasional, serta meningkatkan mutu hidup, daya saing, pengembangan karakter, dan meningkatkan kemampuan yang dibutuhkan di abad 21 ini melalui Gerakan Literasi Nasional. Pada kegiatan literasi ini ada 6 literasi dasar yang harus dikuasi oleh masyarakat Indonesia, ada literasi bahasa, numerasi, digital, literasi sains, finansial, serta literasi kebudayaan dan kewargaan (TIM GLN sKemendikbud,2017a). Salah satu yang paling penting adalah literasi numerasi.

Indonesia merupakan negara yang memiliki kemampuan literasi numerasi yang sangat rendah, dibandingkan negara - negara di Asia Tenggara. Tasyanti, Wardono, dan Rochmad (2018) menjelaskan bahwa hasil keikutsertaan Indonesia dalam TIMMS dan PISA belum memuaskan, hal ini terlihat pada pencapaian dalam kompetensi matematika yang kenaikannya belum signifikan, di tahun 2012 Indonesia mendapat 375 poin dan di tahun 2015 mendapat 386 poin. Kenaikan tersebut hanya membawa Indonesia menjadi peringkat 63 dari 70 negara.

Kemudian pada tahun 2016, TIM GLN Kemendikbud (2017b) juga menjelaskan hasil keikutsertaan Indonesia dalam TIMMS dan PISA menduduki peringkat bawah. Ditinjau dari tes PISA tahun 2015 dan TIMSS tahun 2016, PISA mengeluarkan hasil tes matematika Indonesia dengan nilai 387. Kemudian hasil TIMSS Indonesia mendapatkan nilai 395 dengan rata-rata nilai 500.

Hasil PISA 2018 yang dirilis OECD (2019) juga menunjukan rata-rata skor matematika siswa Indonesia mencapai 379 dengan skor rata-rata OECD 487. Hasil tersebut menunjukan bahwa masih rendahnya kemampuan literasi numerasi yang dimiliki siswa yang disebabkan karena banyaknya materi yang diujikan TIMMS dan PISA berupa soal-soal yang bersifat masalah konteks dalam kehidupan nyata, sedangkan siswa belum terbiasa memecakan suatu masalah yang bersifat nyata dan tidak mampu menganalisis informasi dalam berbagai bentuk.

Literasi numerasi merupakan kemampuan yang didapat siswa setelah mengalami perubahan kesanggupan dalam memperoleh, menginterpretasikan, mengaplikasikan, dan mengkomunikasikan bilangan atau simbol terkait matematika dasar dalam memecahkan masalah pada kehidupan nyata dan menganalisis informasi dalam berbagai bentuk (narasi, grafik, tabel, bagan, dll) untuk mengambil suatu keputusan (Mahmud dan Pratiwi, 2019). Sedangkan siswa Indonesia belum cakap dalam mengaitkan atau menerapkan pengetahuan matematika yang mereka punya dalam berbagai situasi. Kemudian siswa juga kurang mampu menerjemahkan kalimat dan simbol matematika, serta menuliskan atau merepresentasikan informasi yang diberikan (Tasyanti, Wardono, dan Rochmad, 2018) .

Adapun pembelajaran yang masih bergantung pada guru, dimana guru hanya menggunakan pembelajaran konvensional, sehingga siswa kurang aktif dalam pelaksanaan pembelajaran. Guru diharapkan memberikan pembelajaran yang membiasakan siswa mengambil keputusan dalam memecahkan suatu masalah dengan pengetahuan matematika yang mereka punya dan membuat hubungan antara numerasi dengan kehidupan siswa. Guru sebagai pendidik mampu menciptakan pembelajaran yang bermakna dan kondusif sesuai model pembelajaran yang digunakan dan mampu 
Pengaruh Problem Based Learning Berbantuan Media Youtube Terhadap Kemampuan Literasi Numerasi Siswa, Dyah Ambarwati, Meyta Dwi Kurniasih

meningkatkan perhatian siswa melalui sumber atau media pembelajaran yang memicu semangat siswa dalam belajar (Tasyanti, Wardono, dan Rochmad, 2018).

Dari permasalahan tersebut diperlukan model pembelajaran yang tepat dan inovatif. Maka dari itu proses belajar mengajar harus dirubah dari konvensional menjadi pembelajaran yang berbasis masalah. Indah, Mania, dan Nursalam (2016) menjelaskan Problem Based Learning merupakan pembelajaran dimana siswa terlibat aktif dalam memecahkan masalah yang kontekstual. Pada pembelajaran ini, siswa menyelidiki, menggali dan menemukan konsep atau pengetahuanya sendiri yang diperoleh pada saat pemecahan masalah.

Problem Based Learning ini cocok digunakan untuk meningkatkan literasi numerasi siswa, karena proses pembelajarannya mencakup indikator kemampuan literasi numerasi, dimana pada langkah-langkah $P B L$ ini siswa berdiskusi bersama kelompoknya menyelesaikan lembar permasalahan yang diberikan, hal ini mencakup indikator 1 yaitu bekerja secara efektif dengan model dalam situasi konkret dan pada indikator 3 yaitu menggunakan keterampilan dan bernalar dengan beberapa pengetahuan. Kemudian pada langkah mengumpulkan informasi untuk memecahkan masalah mencakup indikator 2 yaitu memilih dan merepresentasikan informasi, dan menghubungkan mereka dengan situasi nyata. Saat siswa menyajikan hasil diskusi mencakup indikator 4 dimana siswa memberikan penjelasan berdasarkan tindakan mereka dari hasil diskusi.

Namun penggunaan model pembelajaran saja tidak cukup dan kurang maksimal, sehingga diperlukan media pembelajaran yang membantu siswa dan mampu mendukung proses $P B L$ ini. Dalam penggunaan $P B L$ adapun kekurangannya, menurut Alan dan Afriansyah (2017) jika pemahaman yang dimiliki siswa kurang, maka akan mempengaruhi sulitnya penyelesaian masalah yang dilakukan siswa dan pembelajarannya membutuhkan waktu yang cukup lama. Dari kekurangan $P B L$ diperlukanlah media di abad 21 ini yang mampu mempermudah pemahaman siswa dalam memecahkan dan menyelesaikan permasalahan yang diberikan, yaitu menggunakan media YouTube.

YouTube merupakan media audio visual/digital yang saat ini sedang populer dan berkembang sangat pesat, dimana seluruh masyarakat dengan mudah mengaksesnya. Media YouTube merupakan media pembelajaran berbasis teknologi informasi dan komunikasi yang digunakan untuk mendorong kreativitas siswa agar lebih aktif, agar siswa membuat perancangan dan menemukan konsepnya dengan usaha sendiri (Nolaputra, Wardono, dan Supriyono, 2018).

Dalam penggunan YouTube ini sebagai alat bantu dalam menggali informasi berupa video pembelajaran terkait materi yang mampu memberikan pemahaman bagi siswa, sehingga proses pemecahan masalah lebih mudah dan siwa tidak terlalu sulit menyelesaikan permasalahan yang diberikan. Siswa dapat menggali informasi berupa video pembelajaran terkait materi, sehingga mempermudah siswa memahami materi pembelajaran yang dianggap sulit dibandingkan penyampaian secara konvensional. Karena dalam media YouTube ini lebih menarik siswa, sehingga siswa tidak merasa bosan daripada harus mempelajari tulisan dibuku pelajaran (Mujianto, 2019). 
Selain itu, YouTube dapat berkontribusi terhadap kemampuan literasi numerasi dimana saat siswa menggali informasi melalui media YouTube terkait video pembelajaran tentang materi peluang mencakup indikator 1 dimana siswa mampu merepresentasikan informasi terkait pemecahan masalah. Kemudian indikator 2 dan 3, siswa jg dituntut bekerja dan bernalar dalam menentukan serta memahami video pada media YouTube tersebut. Dan indikator 4 pada tahap evaluasi diberikan link chanel YouTube yang dibuat guru berisi materi dan soal literasi numerasi. Hal ini juga termasuk kedalam komponen literasi numerasi, yaitu pemanfaatan alat/media dan teknologi.

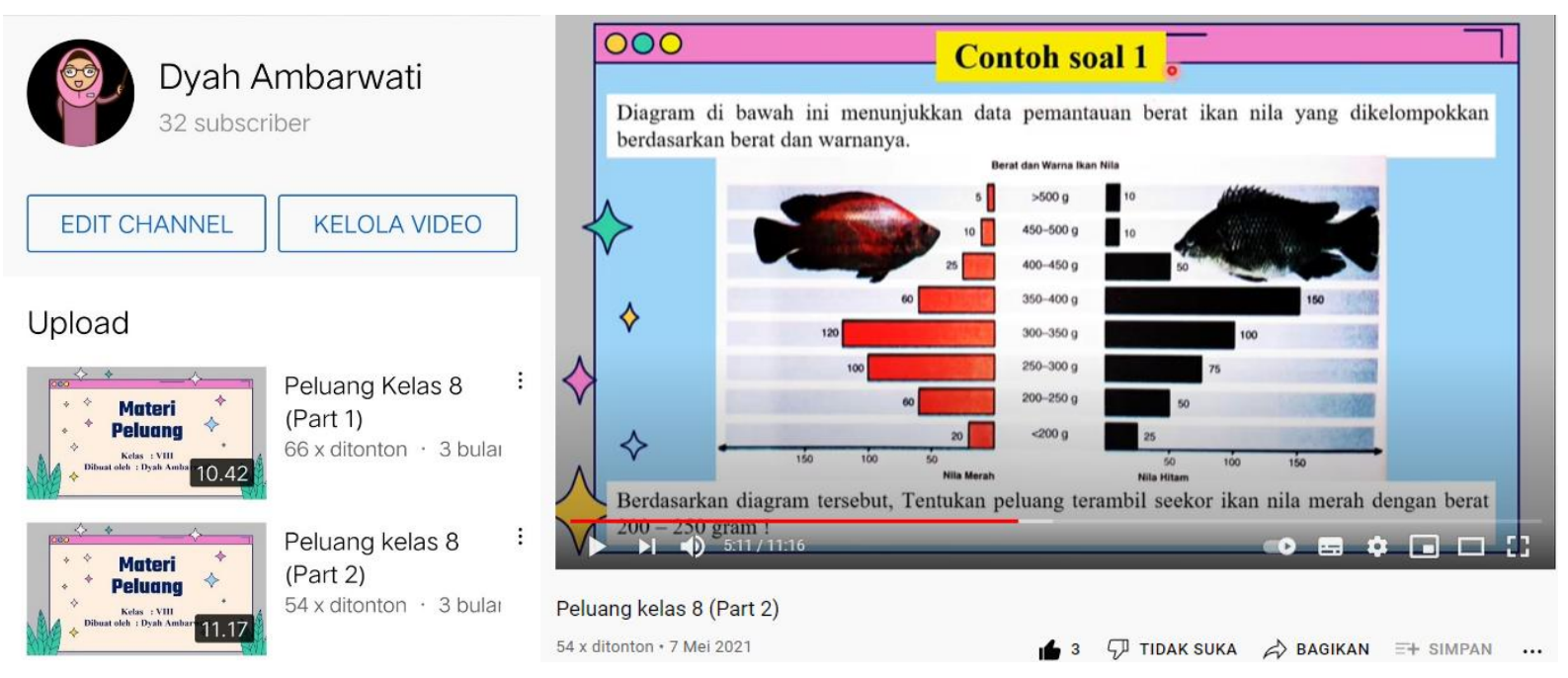

Gambar 1. Gambar Media YouTube yang diberikan

Berdasarkan penelitian sebelumnya yang dilakukan oleh Indah, Mania, dan Nursalam (2016) menyatakan bahwa penggunaan Problem Based Learning di kelas mampu meningkatkan kemampuan literasi matematika siswa kelas VII di SMPN 5 Pallangga Kabupaten Gowa pada materi segitiga dan segiempat. Ditinjau dari hasil rata-rata pretest siswa sebelum perlakuan yaitu sebesar 43,70 dan setelelah perlakuan Problem Based Learning diperoleh rata-rata postest 51,35. Kemudian dari hasil Paired Sample T-test diperoleh nilai 0,000 dengan taraf signifikan 0,05.

Penelitian oleh Firdaus, Wahyudin, dan Herman (2017) mengenai peningkatan literasi matematika, menyatakan terdapat perbedaan signifikan dalam peningkatan literasi matematika siswa yang diajar menggunakan Problem Based Learning dan Direct Instruction. Hasil penelitian tersebut menunjukkan Problem Based Learning dan Direct Instruction memiliki pengaruh yang lebih signifikan terhadap literasi matematika.

Penelitian oleh Widiastuti dan Kurniasih (2021) menyatakan bahwa penggunaan Problem Based Learning dengan bantuan Software Cabri 3D V2 berpengaruh terhadap literasi numerasi siswa, ditinjau dari hasil uji besar pengaruh dihasilkan nilai sebesar 1,237538 termasuk kategori tinggi. Dari penelitian tersebut menunjukkan Problem Based Learning berbantu software cabri 3D memberikan pengaruh yang signifikan dalam literasi numerasi siswa. 
Pengaruh Problem Based Learning Berbantuan Media Youtube Terhadap Kemampuan Literasi Numerasi Siswa, Dyah Ambarwati, Meyta Dwi Kurniasih

Kemudian dalam kaitannya terhadap video pembelajaran pada media YouTube, adapun penelitian terkait oleh Winarni dkk (2021) dalam penggunaan video pembelajaran. Hasil penelitian uji multivariate dan uji T2 Hotelling, $H_{o}$ ditolak. Dari penelitiannya dinyatakan pada kelas eksperimen menggunakan video pembelajaran memiliki kemampuan literasi numerasi dan digital lebih baik dari kelas kontrol. Sehingga penggunaannya sangat efektif dalam meningkatkan literasi numerasi dan literasi digital siswa.

Selain itu, adapun penelitian sebelumnya oleh Juriah \& Zulfiani (2019) menyatakan bahwa Problem Based Learning berbantu media video ini dapat meningkatkan hasil belajar peserta didik. Ditinjau dari rata - rata N-Gain pencapian hasil belajar pada siklus I adalah 0,67 dan pada siklus III 0,79 dengan pemahaman kategori tinggi. Aktifitas peserta didik juga meningkat pada siklus I dari 89\% menjadi $100 \%$ pada siklus II.

Penelitian yang dilakukan oleh Tohari, Mustaji, Bachri (2019) mengenai motivasi dan hasil belajar dalam penggunaan media YouTube. Dari hasil uji- $t$ diperoleh signifikansi $0,000<0,05$ maka terdapat perbedaan rata-rata posttest kelas eksperimen dan kelas kontrol pada hasil belajar, kemudian dari uji Regresi Linier menunjukkan pengaruh yang signifikan antara motivasi belajar dengan hasil belajar. Dalam penelitian tersebut terbukti bahwa pembelajaran matematika menggunakan video dalam media YouTube ini memberi pengaruh dalam meningkatkan proses pembelajaran.

Dari pengaruh positif yang diberikan pada model pembelajaran Problem Based Learning, serta pengaruh media YouTube ini. Maka, peneliti tertarik untuk mengukurnya pada kemampuan literasi numerasi siswa yang dinilai sangat rendah. Sehingga diperlukan penelitian lebih lanjut mengenai Problem Based Learning berbantu media YouTube yang diharapkan mampu memberikan pengaruh dalam meningkatkan kemampuan literasi numerasi siswa. Maka, tujuan penelitian ini untuk mengetahui pengaruh Problem Based Learning berbantu media YouTube terhadap kemampuan literasi numerasi siswa. Adapun variabel bebas dalam penelitian ini adalah Problem Based Learning berbantu media YouTube (X) dan variabel terikatnya adalah kemampuan literasi numerasi siswa (Y).

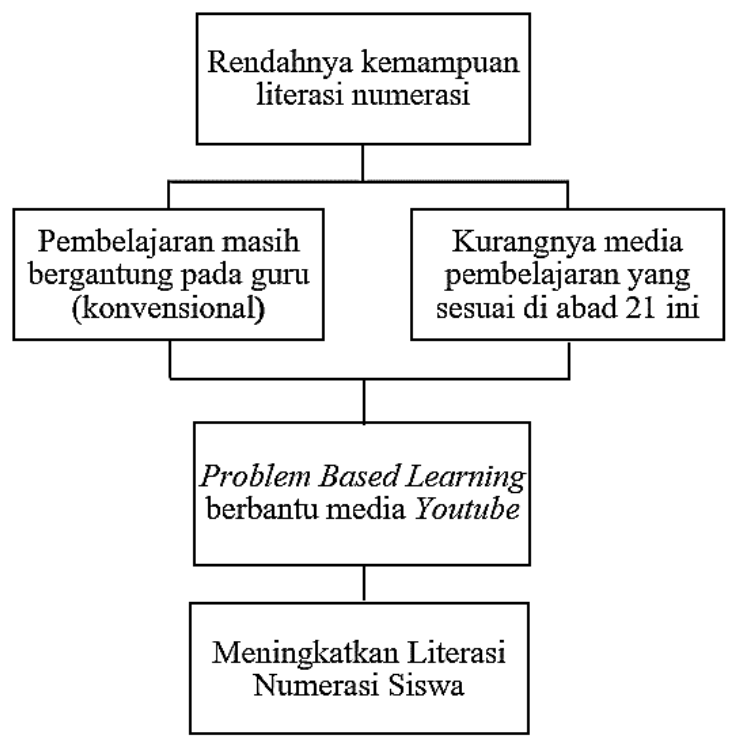

Gambar 2. Kerangka konseptual 


\section{METODE}

Metode penelitian yang digunakan adalah kuantitatif, jenis True Eksperimental Design. Dengan pengambilan sampel secara acak dari populasi tertentu (Sugiyono, 2016: 114). Penelitian dilaksanakan di SMP Negeri 62 Jakarta. Populasi mencakup seluruh siswa kelas VIII pada semester genap tahun ajaran 2020/2021 yang terdiri dari 8 kelas dengan total 288 siswa. Jumlah sampel terdiri dari 2 kelas, yaitu kelas VIII-4 sebagai kelas eksperimen dan kelas VIII-3 sebagai kelas kontrol, dimana masingmasing kelas terdiri dari 36 siswa. Teknik pengambilan sampel menggunakan cluster random sampling, karena diambil secara acak berdasarkan daerah populasi yang tidak diubah atau tetap dan merupakan kelompok sampel yang homogen.

Pada kelas eksperimen diberikan perlakuan menggunakan Problem Based Learning berbantu media YouTube dan kelompok kontrol tanpa menggunakan Problem Based Learning berbantu media YouTube atau dengan konvensional. Untuk desain penelitian menggunakan Posttest Only Control Group Design yang diberikan di akhir pembelajaran. Adapun desainnya seperti gambar dibawah ini.

\begin{tabular}{|lll|}
\hline Eksperimen (R) & $\mathrm{X}$ & $\mathrm{O}_{2}$ \\
Kontrol (R) & & $\mathrm{O}_{4}$ \\
\hline
\end{tabular}

\section{Gambar 3 Desain Posttest only control group design}

Keterangan:

$\mathrm{R}:$ Kelas dipilih secara acak

X : Perlakuan menggunakan Problem Based Learning berbantu media YouTube

$\mathrm{O}_{2}:$ Posttest kemampuan literasi numerasi kelas eksperimen

$\mathrm{O}_{4}$ : Posttest kemampuan literasi numerasi kelas kontrol

Instrumen berupa tes kemampuan literasi numerasi pada materi peluang. Posttest yang diberikan berupa 5 butir soal uraian yang sebelumnya telah melewati uji kelayakan/validasi terlebih dahulu. Pengujian dilakukan oleh validasi ahli, validasi panel, dan validasi empiris. Instrumen telah divalidasi ahli oleh 2 dosen pendidikan matematika, 1 guru matematika SMP, dan validasi panel oleh rekan sesama peneliti. Kemudian validasi empiris yang diujicobakan kepada siswa bukan sampel. Dari perhitungan uji coba instrumen validitas menggunakan Product Moment diperoleh 5 butir soal dinyatakan Valid. Sedangkan uji reliabilitas menggunakan Cronbach's Alpha didapatkan koefisien reliabilitas $\left(\mathrm{r}_{11}\right)$ sebesar 0,826 yang memiliki korelasi kategori sangat tinggi. Sehingga Instrumen layak untuk penelitian.

Analisis data menggunakan uji prasyarat normalitas dan homogenitas, uji hipotesis $t$-test, dan selanjutnya effect size.

\section{HASIL DAN DISKUSI}

Sebelum dilakukan penelitian dilakukan uji normalitas dan homogenitas sampel kelas VIII-3 dan VIII-4 untuk mengetahui kondisi awal apakah sampel yang diambil berdistribusi normal dan homogen. Data diperoleh dari hasil Penilaian Tengah Semester (PTS), dimana kelas kelas VIII-3 (kelas kontrol) 
Pengaruh Problem Based Learning Berbantuan Media Youtube Terhadap Kemampuan Literasi Numerasi Siswa, Dyah Ambarwati, Meyta Dwi Kurniasih

memiliki $L_{\text {hitung }}=0,130<L_{\text {tabel }}=0,150$ dan kelas VIII-4 (kelas eksperimen) memiliki $L_{\text {hitung }}=$ $0,111<L_{\text {tabel }}=0,150$, dimana kedua sampel berdistribusi normal. Dari uji homogenitas diperoleh nilai $F_{\text {hitung }}=1,545<F_{\text {tabel }}=1,757$, sehingga kelas kontrol dan eksperimen memiliki sampel yang homogen.

Penelitian ini dilakukan selama 3 pertemuan pada kelas kontrol dan kelas eksperimen. Adapun Indikator yang digunakan sebagai berikut.

Tabel 1. Indikator Literasi Numerasi Level 4

\begin{tabular}{|c|l|c|}
\hline No. & \multicolumn{1}{|c|}{ Indikator } & Soal Butir \\
\hline 1. & Bekerja secara efektif dengan model dalam situasi konkret dan kompleks. & $1,2,3,4,5$ \\
\hline 2. & $\begin{array}{l}\text { Memilih dan merepresentasikan informasi, termasuk pada simbol, dan } \\
\text { menghubungkan mereka dengan situasi nyata. }\end{array}$ & $1,2,3,4,5$ \\
\hline 3. & $\begin{array}{l}\text { Menggunakan keterampilan dan bernalar dengan beberapa pengetahuan } \\
\text { dalam konteks langsung. }\end{array}$ & $1,2,3,4,5$ \\
\hline 4. & $\begin{array}{l}\text { Memberikan penjelasan dan mengkomunikasikannya disertai alasan dan } \\
\text { argumentasi berdasarkan interpretasi dan tindakan mereka. }\end{array}$ & $1,2,3,4,5$ \\
\hline
\end{tabular}

Adapun langkah-langkah Problem Based Learning berbantu media YouTube yang dilakukan oleh peneliti, sebagai berikut :

1. Mengorientasi siswa pada masalah

Sebelum pembelajaran dimulai, peneliti menjelaskan tujuan pembelajaran yang ingin dicapai dan memberikn motivasi. Kemudian peneliti menampilkan permasalahan terkait dengan materi peluang kejadian. Peneliti mendorong rasa ingin tahu siswa, sehingga siswa mengajukan pertanyaan terkait permasalahan yang ditampilkan.

2. Mengorganisasikan siswa belajar

Peneliti memberikan lembar permasalahan dan menanyakan kepada siswa bagaimana cara menyelesaikan permasalahan tersebut dan membagi 9 kelompok, 1 kelompok terdiri dari 4 siswa. Peneliti menjelaskan arahan yang akan dilakukan pada kelompok tersebut untuk berkolaborasi menyelesaikan lembar permasalahan yang telah diberikan.

3. Membimbing penyelidikan

Peneliti membimbing penyelidikan kelompok untuk mencari informasi terkait permasalahan materi peluang yang diberikan, untuk mendapatkan penjelasan dalam memecahkan permasalahan yang diberikan, peneliti menyuruh siswa untuk berdiskusi menggali informasi sebanyakbanyaknya pada media YouTube dalam menyelesaikan permasalahan. Kemudian menyuruh siswa untuk mencantumkan link video YouTube yang telah dicari pada lembar pengerjaan.

4. Mengembangkan dan menyajikan hasil karya

Pada tahap ini peneliti meminta tiap kelompok memamparkan hasil diskusinya, kemudian kelompok lain memberikan tanggapan terhadap kelompok yang persentasi. Dari penyajian terkait 
materi peluang, ada beberapa yang menjadi perdebatan antar kelompok. Salah satunya adalah permasalahan mengenai percobaan Wisnu melempar 2 keping uang logam secara bersama sebanyak 1 kali. Kemudian siswa mentukan peluang kejadian terbuka sisi angka dan gambar. Dari hasil penyajian atau persentasi kelompok tersebut, terdapat kelompok yang memiliki tanggapan atau hasil yang berbeda. Kelompok yang persentasi mendapatkan peluang kejadian terbuka sisi angka dan gambar sebesar $\frac{1}{2}$.

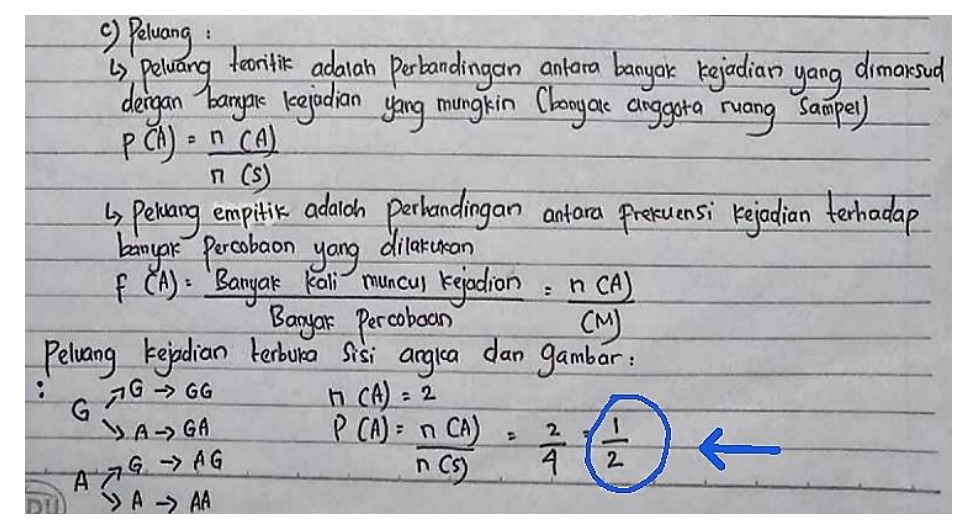

Gambar 4. Hasil kelompok persentasi

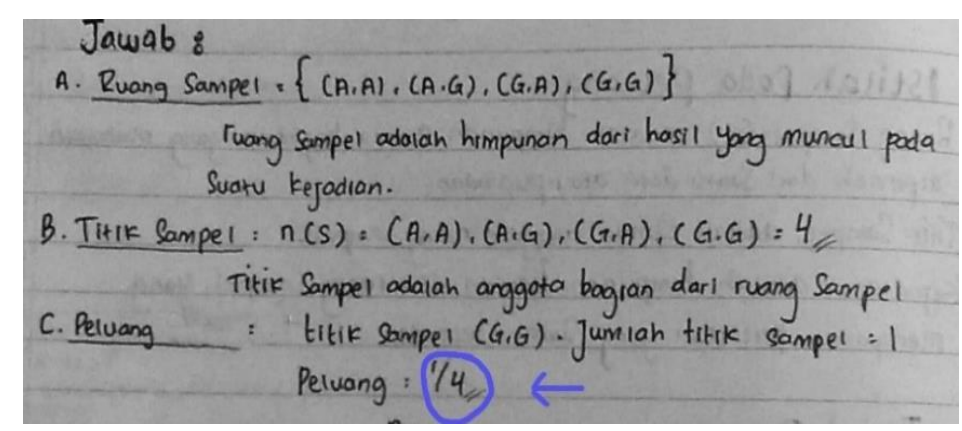

Gambar 5. Hasil Kelompok Penyanggah

Setelah kelompok yang persentasi memaparkan dan menjelaskan hasil diskusinya, terdapat kelompok lainnya yang memberikan tanggapan dengan jawaban yang berbeda, yaitu dengan hasil $\frac{1}{4}$. Dari hasil tersebut peneliti menyuruh kelompok yang menanggapi untuk memberikan penjelasan dan proses penyelesaiannya yang dikerjakannya.

5. Menganalisis dan mengevaluasi proses pemecahan masalah.

Pada tahap ini peneliti mengonfirmasi jawaban/ hasil diskusi yang benar, membantu siswa untuk menyimpulkan materi yang telah dibahas, dan memberikan link video YouTube yang dibuat oleh guru sebagai evaluasi siswa sehingga siswa dapat mempelajarinya kembali.

\section{Deskripsi Data}

Berdasarkan deskripsi data hasil posttest literasi numerasi pada kelas eksperimen dan kelas kontrol. Adapun sebaran data penelitian tersebut meliputi rata-rata, median, modus, rentang, varians, dan simpangan baku. Hasil perhitungan dapat dilihat pada tabel 2. 
Pengaruh Problem Based Learning Berbantuan Media Youtube Terhadap Kemampuan Literasi Numerasi Siswa, Dyah Ambarwati, Meyta Dwi Kurniasih

Tabel 2. Deskripsi Data Kemampuan Literasi Numerasi Siswa

\begin{tabular}{|c|c|c|c|c|c|c|}
\hline Kelas & Mean & Median & Modus & $\begin{array}{c}\text { Simpangan } \\
\text { Baku }\end{array}$ & Varians & $\begin{array}{c}\text { Rentang } \\
\text { (Range) }\end{array}$ \\
\hline Eksperimen & 41,08 & 42,50 & 44 & 6,077 & 36,936 & 26 \\
\hline Kontrol & 35,64 & 37,00 & $35,38, \& 43$ & 7,665 & 58,752 & 30 \\
\hline
\end{tabular}

Perhitungan posttest kemampuan literasi numerasi siswa diatas, dapat dideskripsikan bahwa pada kelas eksperimen memiliki rata - rata literasi numerasi sebesar 41,08, nilai tengah (median) 42,50, modus 44, simpangan baku 6,077, variansi 36,936, dan memiliki rentang 26. Kemudian pada kelas kontrol memiliki rata - rata sebesar 35,64, nilai tengah (median) 37,00 , modus $35,38, \& 43$, simpangan baku 7,665, dan variansi adalah 58,752. Dari hasil tersebut diperoleh rata-rata kelas eksperimen lebih tinggi, yaitu 41,08 dibandingkan dengan skor rata-rata kelas kontrol 35,64.

\section{Uji Normalitas}

Sebelum dilakukan uji hipotesis, terlebih dahulu dilakukan uji prasyarat analisis yaitu uji normalitas dan uji homogenitas. Pada pengujian normalitas ini dilakukkan menggunakan uji lilliefors. Sampel berdistribusi normal jika memenuhi kriteria $L_{\text {hitung }}<L_{\text {tabel }}$ pada taraf signifikan $5 \%$. Berikut hasil perhitungan uji normalitas pada tabel 3 .

Tabel 3. Hasil Uji Normalitas

\begin{tabular}{|c|c|c|}
\hline \multirow{2}{*}{ Uji lilliefors } & \multicolumn{2}{|c|}{ Kelas } \\
\cline { 2 - 3 } & Eksperimen & Kontrol \\
\hline$L_{\text {hitung }}$ & 0,071 & 0,088 \\
\hline$L_{\text {tabel }}$ & 0,150 & 0,150 \\
\hline Keterangan & Normal & Normal \\
\hline
\end{tabular}

Dari uji normalitas posttest kemampuan literasi numerasi kelas eksperimen memiliki $L_{\text {hitung }}=$ $0,071<L_{\text {tabel }}=0,150$ maka hasil posttest kelas eksperimen dinyatakan berdistribusi normal. Sedangkan posttest kemampuan literasi numerasi kelas kontrol memiliki $L_{\text {hitung }}=0,088<L_{\text {tabel }}=$ 0,150 maka hasil posttest kelas kontrol juga berdistribusi normal. Hasil tersebut menunjukkan posttest masing-masing kelas eksperimen dan kelas kontrol berdistribusi normal. Dengan demikian uji homogenitas dapat dilakukan.

\section{Uji Homogenitas}

Uji homogenitas yang digunakan uji kesamaan kedua varians menggunakan uji $\mathrm{F}$ pada data posttest kemampuan literasi numerasi siswa. Sampel dikatakan memiliki varians yang homogen apabila $\mathrm{F}_{\text {hitung }}<\mathrm{F}_{\text {tabel }}$ pada taraf signifikan 5\%. Berikut ringkasan hasil uji homogenitas dijelaskan pada tabel 4.

Tabel 4. Hasil Uji Homogenitas

\begin{tabular}{|c|c|c|c|}
\hline Uji Homogenitas & $\boldsymbol{F}_{\text {hitung }}$ & $\boldsymbol{F}_{\text {tabel }}$ & Keputusan \\
\hline $\begin{array}{c}\text { Kelas eksperimen \& } \\
\text { kelas kontrol }\end{array}$ & 1,591 & 1,757 & $\begin{array}{c}\mathrm{H}_{\mathrm{o}} \text { : diterima } \\
\text { Kedua varians homogen }\end{array}$ \\
\hline
\end{tabular}


Berdasarkan hasil perhitungan, diperoleh $F_{\text {hitung }}=1,591<F_{\text {tabel }}=1,757$ pada taraf signifikan 5\%. Maka, dapat disimpulkan bahwa pada kelas kontrol dan kelas eksperimen memiliki varians yang sama atau homogen. Karena posttest berdistribusi normal dan variansinya homogen. Sehingga dapat dilanjutkan uji hipotesis.

Uji-t

Setelah posttest kemampuan literasi numerasi kelas kontrol \& eksperimen berdistribusi normal dan memiliki varians homogen, selanjutnya dilakukan uji hipotesis menggunakan uji-t.

Tabel 5. Hasil Uji-t

\begin{tabular}{|c|c|c|}
\hline $\boldsymbol{t}_{\text {hitung }}$ & $\boldsymbol{t}_{\text {tabel }}$ & Keputusan \\
\hline 3,339 & 1,994 & $\mathrm{H}_{\mathrm{a}}$ diterima \\
\hline
\end{tabular}

Berdasarkan tabel di atas nilai $t_{\text {hitung }}$ yang didapat sebesar 3,339 dan nilai $t_{\text {tabel }}$ sebesar 1,994. Hal ini menunjukan bahwa nilai $t_{\text {hitung }}$ lebih besar daripada nilai $t_{\text {tabel }}$ pada taraf signifikan $5 \%$. Maka dapat dituliskan $t_{\text {hitung }}=3,339>t_{\text {tabel }}=1,994$. Sehingga dapat disimpulkan bahwa $t_{\text {hitung }}$ berada di daerah penerimaan $\mathrm{H}_{\mathrm{a}}$ dan $H_{o}$ ditolak. Artinya terdapat perbedaan rata-rata literasi numerasi pada kelas eksperimen yang diajarkan dengan Problem Based Learning berbantu media YouTube dan kelas kontrol yang tidak menggunakan Problem Based Learning berbantu media YouTube.

\section{Uji Effect Size}

Effect size ini digunakan untuk mengetahui besarnya pengaruh Problem Based Learning berbantu media YouTube. Dari pengujian Effect Size dengan cohen's yang telah dilakukan, diperoleh Effect size sebesar 0,710 dengan interpretasi kategori sedang. Sehingga Problem Based Learning berbantu media YouTube ini mampu memberikan pengaruh sedang dalam meningkatkan literasi numerasi.

Dari hasil tersebut menunjukkan penggunaaan Problem Based Learning berbantu media YouTube berpengaruh dan lebih baik dari kovensional terhadap literasi numerasi. Dikarenakan proses pembelajaran pada kelas eksperimen ini terdapat perlakuan dimana siswa berdiskusi bersama kelompoknya dengan menggali informasi melalui media YouTube untuk memecahkan dan menyelesaikan permasalahan kontekstual yang diberikan, serta diberikan evaluasi pembelajaran berupa video yang dibuat guru pada media YouTube ini. Sedangkan kelas kontrol tanpa menggunakan Problem Based Learning berbantu media YouTube atau dengan konvensional, dimana siswa hanya siswa terpaku pada materi yang diberikan guru saja.

\section{KESIMPULAN}

Dari penelitian ini didapatkan nilai rata-rata tes kemampuan literasi numerasi kelas eksperimen lebih tinggi sebesar 41,08 dari kelas kontrol dengan rata-rata 35,64. Dari hasil uji- $t$ diperoleh $t_{\text {hitung }}$ sebesar 3,339 dan $t_{\text {tabel }} 1,994$ pada taraf signifikan 5\%, artinya terdapat perbedaan yang signifikan antara kelas kontrol dan kelas eksperimen. Dilihat dari hasil penelitian kelas eksperimen lebih baik dari kelas kontrol, karena menggunakan Problem Based Learning berbantu media YouTube yang 
Pengaruh Problem Based Learning Berbantuan Media Youtube Terhadap Kemampuan Literasi Numerasi Siswa, Dyah Ambarwati, Meyta Dwi Kurniasih

membentuk siswa secara aktif dalam kegiatan pembelajaran dengan berdiskusi serta menggali informasi melalui media YouTube. Kemudian diperoleh Effect Size sebesar 0,710 dengan interpretasi kategori sedang. Maka disimpulkan pada penelitian ini menunjukkan pengaruh Problem Based Learning berbantu media YouTube dalam meningkatkan literasi numerasi siswa kelas VIII. Oleh karena itu, peneliti selanjutnya diharapkan menyelidiki model dan media pembelajaran lainnya yang mampu meningkatkan kemampuan literasi numerasi siswa.

\section{UCAPAN TERIMA KASIH}

Peneliti berterimakasih kepada kedua orang tua, selaku dosen pembimbing Meyta Dwi Kurniasih, M.Pd. yang telah membimbing peneliti, selaku ahli validasi instrumen Leni Marlena, S.Stat., M.Si., Windia Hadi, M.Pd., dan Divo Ichwan Pradiqa, S.Pd.. Kepala sekolah, guru, dan siswa SMPN 62 Jakarta. Serta seluruh pihak terkait yang sudah mendukung dan memberikan kontribusi kepada peneliti sehingga penelitian ini dapat terlaksana dengan baik.

\section{REFERENSI}

Alan, U. F., \& Afriansyah, E. A. (2017). Kemampuan Pemahaman Matematis Siswa Melalui Model Pembelajaran Auditory Intellectualy Repetition dan Problem Based Learning. Jurnal Pendidikan Matematika, 11(1), 67-78. https://doi.org/10.22342/jpm.11.1.3890.67-78

Firdaus, F. M., Wahyudin, \& Herman, T. (2017). Improving Primary Students Mathematical Literacy Through Problem Based Learning and Direct Instruction. Educational Research and Reviews, 12(4), 212-219. https://doi.org/10.5897/ERR2016.3072

Indah, N., Mania, S., \& Nursalam. (2016). Peningkatan Kemampuan Literasi Matematika Siswa Melalui Penerapan Model Pembelajaran Problem Based Learning Di Kelas VII SMP Negeri 5 Pallangga Kabupaten Gowa. MaPan, 4(2), 200-210. https://doi.org/10.24252/mapan.2016v4n2a4

Juriah, \& Zulfiani. (2019). Penerapan Model Problem Based Learning Berbantu Media Video untuk Meningkatkan Hasil Belajar Peserta Didik pada Konsep Perubahan Lingkungan dan Upaya Pelestarian. EDUSAINS, 11(1), 1-11. https://doi.org/10.15408/es.v11i1.6394

Mahmud, M. R., \& Pratiwi, I. M. (2019). Literasi Numerasi Siswa Dalam Pemecahan Masalah Tidak Terstruktur. KALAMATIKA Jurnal Pendidikan Matematika, 4(1), 69-88. https://doi.org/https://doi.org/10.22236/KALAMATIKA.vol4no1.2019pp69-88

Mujianto, H. (2019). Pemanfaatan Youtube Sebagai Media Ajar dalam Meningkatkan Minat dan Motivasi Belajar. Jurnal Komunikasi Hasil Pemikiran Dan Penelitian, 5(1), 135-159. https://journal.uniga.ac.id/index.php/JK/article/view/588/566

Nolaputra, A. P., Wardono, \& Supriyono. (2018). Analisis Kemampuan Literasi Matematika pada Pembelajaran PBL Pendekatan RME Berbantuan Schoology Siswa SMP. Prosiding Seminar 
Nasional

Matematika,

1,

$18-32$.

https://journal.unnes.ac.id/sju/index.php/prisma/article/view/19672

OECD. (2019). Programme for International Student Assessment (PISA) Result From PISA 2018. OECD Publishing, I-III, 1-10. https://doi.org/https://doi.org/10.1787/5f07c754-en

Sugiyono. (2016). Metode Penelitian Pendidikan Pendekatan Kuantitatif, Kualitatif, R\&D. Bandung: Alfabeta.

Tasyanti, T., Wardono, \& Rochmad. (2018). Analisis Kemampuan Literasi Matematika Berdasarkan Kecerdasan Emosional Siswa Melalui Model Pembelajaran Kooperatif Tipe Group Investigation. PRISMA, Prosiding Seminar Nasional Matematika, 1, 334-346. https://journal.unnes.ac.id/sju/index.php/prisma/article/view/19611

TIM GLN Kemendikbud, S. (2017a). Gerakan Literasi Nasional. Jakarta: Kemendikbud. https://gln.kemdikbud.go.id/glnsite/

TIM GLN Kemendikbud, S. (2017b). Materi Pendukung Literasi Numerasi. Jakarta: Kemendikbud. https://gln.kemdikbud.go.id/glnsite/category/literasi-numerasi/

Tohari, H., Mustaji, Nf., \& Bachri, B. S. (2019). Pengaruh Penggunaan YouTube terhadap Motivasi Belajar dan Hasil Belajar Mahasiswa. Kwangsan: Jurnal Teknologi Pendidikan, 7(1), 1-13. https://doi.org/10.31800/jtp.kw.v7n1.p1--13

Widiastuti, E. R., \& Kurniasih, M. D. (2021). Pengaruh Model Problem Based Learning Berbantuan Software Cabri 3D V2 terhadap Kemampuan Literasi Numerasi Siswa. Jurnal Cendekia : Jurnal Pendidikan Matematika, 5(2), 1687-1699. https://doi.org/10.31004/cendekia.v5i2.690

Winarni, S., Kumalasari, A., Marlina, \& Rohati. (2021). Efektivitas Video Pembelajaran Matematika Untuk Mendukung Kemampuan Literasi Numerasi dan Digital Siswa. AKSIOMA: Jurnal Program $\begin{array}{llll}\text { Studi Pendidikan } \quad \text { Matematika, } & \text { 574-583), }\end{array}$ https://doi.org/https://doi.org/10.24127/ajpm.v10i2.3345. 